\title{
Discussion on the Music Teaching Reform in Primary and Secondary Schools under the Perspective of New Media
}

\author{
$\mathrm{Na} \mathrm{Li}$ \\ Feixian Campus \\ Linyi University \\ Feixian, China 273400
}

\author{
Huihua Liu \\ Feixian Campus \\ Linyi University \\ Feixian, China 273400
}

\begin{abstract}
With the social and economic development and the progress of information technology, the music teaching reform in primary and secondary schools is also in progress. Under the social background that the new media technology gradually becomes mature, the music teaching reform in primary and secondary schools is researched and analyzed from the perspective of new media, and some reform strategies are explored proactively. In the music teaching of primary and secondary schools, the teaching reform will enhance the quality of music teaching, promote the development of music education and drive the improvement of comprehensive quality of primary and secondary school students. According to the physical truth, this paper has explored the way of renovating music teaching under the perspective of new media.
\end{abstract}

\section{Keywords-music teaching; reform; new media}

\section{INTRODUCTION}

When the music teaching reform in primary and secondary schools is proceeding, the soaring development of software and hardware concerning new media has tremendously promoted the progress of music teaching. Under the environment of new media, an increasing number of teachers enjoy applying the information technology to the classroom teaching of music via new media facilities. Applying new media technology to the process of music teaching is a brandnew teaching method, which can improve the quality of music teaching. In this way, teachers and students will make information resources in education transmitted and applied faster and more conveniently via relying on the progress of digital technology and network. Interest is the best teacher. It is easier to stimulate the interest of primary and secondary school students to learn new things. Besides, interest constantly strengthens the ability of primary and secondary school students in understanding and accepting all kinds of new-type electronic equipment. It is conductive to students' learning of knowledge about music. This has greatly promoted the music teaching reform to some extent. The emergence of media has very important significance on improving the music teaching effect in primary and secondary schools.

\section{DeEPly ANALyze the Positioning of Music COURSE SYSTEM}

The deep integration of new media technology and music teaching in primary and secondary schools has brought thriving vitality for music teaching at the meantime brought huge challenges for the vast music teachers. Music teachers in primary and secondary schools have to break the original mindset, continuously learn and improve and integrate knowledge and technology as well as keep abreast of the development of times. The integration of new media technology and music teaching does not mean that we must abandon the traditional music teaching pattern. Instead of neglecting the exercise of playing stringed instruments, singing and dancing, they should attach equal importance to knowledge, skills, emotions and creativity. The application of new media technology is to enable students to possess more rooms for active thinking in the pleasant learning environment. It's unsuitable to simply show off it used by us to connect with the new era.

Under the perspective of new media, the music teaching reform in primary and secondary schools is vigorously promoted, requiring us to analyze the problems in the process of teaching reform in detail and effectively solve them. In the process of music teaching in primary and secondary schools, the positioning of course system is not accurate enough, while the failing of positioning is the problem caused by the unsound music teaching systems in schools. For example, when teaching music, teachers excessively emphasize the basic theoretical knowledge of music, leading to the shortage of practical ability among primary and secondary school students; with too much emphasis on skill training and pursuit of stage performance, the theoretical learning of music knowledge of students will be neglected easily. Therefore, we must make the most of the positive role of new media, guide students to give play to the positive initiative and participate in learning convivially in the process of music teaching. It has guaranteed the sufficient transmission of basic theoretical knowledge in music teaching at the same time guaranteed students have certain opportunities for artistic practice.

In regard to the new problems emerging in the process of music teaching in primary and elementary schools, we need to 
take advantages of new media to carry out deep analysis. In the process of music teaching in primary and secondary schools, the development obstacles caused by unbalanced course distribution easily influence the cultivation of students' comprehensive ability. In addition, unscientific course provision will fail to achieve good effects of classroom teaching and will severely impede students' integrated development. In the learning of music course, primary and secondary schools should give priority to the proportion of courses related to music, courses related to the education of cultural theory and elective courses of skills, in order to meet the requirements of students' integrated development.

A special role played by new media is to provide special information resources required in teaching for teaching objects in advance. In the real process of music teaching, we will provide all the music courses elaborately prepared for students via the network and let students independently select relevant courses whenever and wherever possible according to their learning plan or interests. At the meantime, since the new media is convenient, fast and efficient, we must effectively integrate courses of teaching practice and basic theories, to improve students' active practical ability, let students know more about basic music theories and roundly enhance their music accomplishment.

\section{The Music TeACHING PATtern Is GRAdUALLY OPTIMIZED.}

Under the situation that the music course reform in primary and secondary schools proceeds gradually and the new media technology penetrates into classroom teaching, a large number of music teachers try to make use of new media equipment to increase the frequency of interaction between teachers and students. However, the tremendous and complex tasks of preclass preparation make most teachers teach in the same "process" of teaching interaction according to the same "template", so that the classroom interaction form is single and has lost the expected values. The process of implementing music teaching is sample and formalistic severely.

In the process of music teaching reform in primary and secondary schools, we can further optimize the teaching model to take full advantage of the technological superiority of new media. The traditional music teaching model in primary and secondary schools is relatively fixed for course arrangement, allocation of teachers and has no big changes within a long period of time. Therefore, we improve the education system in universities, devote to cultivate highly professional music teachers with distinctive characteristics in primary and secondary schools, reform our music teaching model and deeply optimize it. The emergence of new media has provided convenient conditions for us. Its characteristic of high-speed transmission on the basis of network information technology has realized the sharing of music teaching resources. We should carry out contrastive analysis on the basic data of students' music learning at present and analyze the future development trend of them. They all have provided crucial objective conditions for us to conduct efficient teaching. The introduction of art module of new media is a highlight brought by the course reform for music teaching in primary and secondary schools. However, from the perspective of survey result, the implementation of art education of new media in primary and secondary schools is unfavorable and has encountered not a few obstacles, and the development fails to keep up with the times. Music teachers in primary and secondary schools are not familiar with art knowledge of new media and are short of the ability of technical operation. The influence of inexpertness of software application has exceeded that of simple hardware equipment. They have become the major reasons that impede the implementation of art module of new media in primary and secondary schools. In the questionnaire, music teachers in primary and secondary schools have the following prominent problems in applying new media and showing courseware: they teach with teaching syllabus that replaces the contents of courseware; let students see video instead of give appreciation class; fail to prepare courseware before class but directly project textbooks, teaching materials and pictures or teach only through amplification system; directly download courseware similar to teaching materials and incompatible to students' practical situation from the network; the courseware contents are general and lack appreciation and interaction with low quality.

Under the new media environment, the music teaching model is optimized continuously and deeply. Students become the subject while teachers become counselor and guide in classroom teaching. The process of classroom teaching needs the joint participation of teachers and students. Not one of them can be dispensed with. First of all, the "duck-stuffing" teaching model of teachers in the traditional teaching should be reformed fundamentally, which will effectively stimulate the learning interests of students, cultivate students into subjects with conscious learning and then give play to the positive initiative. The effective music teaching model under the new media environment bases on the conventional teaching of digital music, further expands and strengthens the interaction in classroom teaching. The interaction between teachers and students has optimized music classroom and created the situation of music evening party in which students are pleased to participate. In the relaxed and cheerful atmosphere, students can fully enjoy the process of learning music knowledge and break through the difficult points in music teaching. Music teachers in primary and secondary schools should reflect and properly adjust teaching contents and ways and use new media technology to learn more advanced teaching methods. Teachers can build the teaching model of music flipped classroom through independently creating music MOOC courses in primary and secondary schools and integrate regular teaching activities with students' independent learning time. In the teaching process, the best effects of teaching will be achieved through the integration of primary and secondary school students and classroom. The optimization of music teaching model moves toward this direction. Schools devote to achieving better learning effects and improving students' comprehensive music accomplishment.

\section{ENHANCE THE INPUT INTENSITY OF MUSIC TEACHING}

The fundamental construction and fund investment of teaching is important guarantee to ensure the improvement of teaching level and quality. The educational input has attracted the high attention of the public in society in a certain period of 
time. In practice, the teaching fund is indeed tight universally. Of course, some teaching resources are used unreasonably and wasted at the same time. Therefore, on one hand, educational institutions should further free their mind, strengthen the vigor of school management and proactively raise teaching fund via multiple channels; on the other hand, they must ensure the limited funds are used to guarantee talent training work in priority through strengthening the reform of internal management system, especially the requirements of teaching and fundamental teaching construction.

To promote the development of music teaching reform in primary and secondary schools under the new media environment, we should gradually intensify the comprehensive input of schools in teachers and facilities in the teaching process. Music education assumes important missions in the development of education system and plays a vital role in training students' comprehensive quality. Under the environment of new media, opportunities and challenges of music teaching coexist. However, the emergence of new media makes us have to adapt to the newest music teaching ways under the new media environment. At the same time, we fail to timely update corresponding matched teaching resources such as computer, sound equipment and shared library of network MOOC resources. Therefore, we should input more funds into music teaching in primary and secondary schools, such as create a good atmosphere of music learning for students, enhance the level of music classroom and expand the influence of music teaching; in the second place, complete teaching tools of new media as the basis and premise of music teaching must be timely updated. The complete teaching tools of new media include: teaching software, sound equipment, projector and high-speed network. It's certain that we must achieve the effect of yielding twice the result with half the effort if we teach students by virtue of the most advanced new media equipment.

Schools should employ music teachers who can grasp new media technology successively and enlighten students to grasp the new media and carry out seamless integration of new media and traditional music teaching. In the teaching with new media as technical guidance, we also devote to ceaselessly improving the professional teaching ability of music teachers and their media literacy. Schools should provide music teachers with opportunities of communication and training related to in-service or out-of-service learning and provide effective resources and favors for teachers in self-development, so that they will become new-type teaches who have high quality and are qualified for new media teaching, assisting the music teaching reform under new media environment and finally achieving better development. In the teaching process, we can introduce educational functions of music such as broadcast, television, music and news to assist music teaching. Some music programs such as music forms of various styles, music schools and performance styles can be implemented in a program specifically. Music teachers collect similar teaching resources of films and televisions and fully apply to our music teaching, in order to let primary and secondary school students grasp the current tendency of music popularity more efficiently and have more enthusiasm in music learning.

\section{CONCLUSION}

In a word, a lot of practices have proved new media music technology as a modern teaching means with strong practicality has shown extremely broad development prospect in the music education of primary and secondary schools. We ensure the popularity and application of new media music technology will inevitably have far-reaching influences on concepts, methods, contents and means of the traditional music teaching system in primary and secondary schools and have broken a brand-new path of music learning for students. It has important practical significance and role on deepening music teaching reform of primary and secondary schools, realizing the modernization of music education and improving the quality and level of music education in our country. Therefore, in the process of music teaching reform in primary and secondary schools, music teaching should conform to the development of the times and make use of new media technology to achieve better effects. We need to deeply research teaching model, analyze problems roundly and grasp the key of problems. Meanwhile, we must explicitly understand the development direction of music teaching and make the best of various convenient conditions of new media and proactively conduct the music teaching reform.

\section{REFERENCES}

[1] Zhao Juanjuan. Analysis and Thinking on the Media Literacy Education of College Students [J], Theory Guide, August, 2011 赵娟娟，对大学 生媒介素养教育的分析与思考 $[\mathrm{J}]$. 理论导报, 2011, 08

[2] Huang Jianjun, Guo Shaoqing. Discussion on the Design and Development of Micro-courses [J], Modern Educational Technology, May, 2013 黄建军, 郭绍青, 论微课程的设计与开发 $[\mathrm{J}]$. 现代教育 技术，2013，05

[3] Wang Yu. Exploration on the Music Appreciation Teaching in Universities under the Environment of New Media [J], Aesthetics of Music, August, 2014 王娱，多媒体环境下的高校音乐鉴赏教学探析 [J]. 音乐美学, 2014, 08

[4] Guo Lingling, Liu Guofeng. Exploration on Ways of Reforming Vocal Music Teaching under the Environment of New Media [J], China Management Informationization, December, 2017 郭玲玲, 刘国 峰. 新媒体环境下声乐教学的革新方式探索 [J].中国管理信息 化, 2017, 12 